\title{
Antidepressant Use and Risk of Venous Thromboembolism: A Systematic Review and Meta-Analysis
}

\author{
Ying Wang, Zhikang Ye, Lihong Liu, Xiangli Cui \\ Department of Pharmacy, Beijing Chao-Yang Hospital, Capital Medical University, Beijing, China. \\ Received, November 30, 2018; Revised, December 3, 2018; Accepted, January 15, 2019; Published, January 17, 2019.
}

\begin{abstract}
Purpose. Studies provided conflicting results on whether antidepressant use increased the risk of venous thromboembolism (VTE). Our aim was to examine the association between antidepressant use and the risk of VTE. Methods. Pubmed, Embase, and the Cochrane Library were searched up to March 13, 2018. Case-control studies and cohort studies that examined the association between antidepressant use and the risk of VTE, deep vein thrombosis or pulmonary embolism were included. Several subgroup analyses and sensitivity analyses were conducted. GRADE approach was used to assess the quality of evidence. Results. Nine studies (six case-control studies and three cohort studies) were included. Overall, antidepressant use may be associated with an increased risk of VTE (OR 1.27, 95\% CI 1.09 to 1.49); however, no association was observed in studies with low risk of bias (OR 1.27, 95\% CI 0.84 to 1.92). No association between selective serotonin reuptake inhibitor use and VTE risk was detected in the overall analysis (OR 1.10, 95\% CI 0.90 to 1.34) and in subgroup analysis of studies with low risk of bias. Tricyclic antidepressant may be associated with an increased VTE risk (OR 1.26, 95\% CI 1.02 to 1.57), and the quality of evidence was rated as very low by GRADE approach; however, no association was observed when we only included studies with low risk of bias. Conclusions. There was no association between selective serotonin reuptake inhibitor use and VTE risk. Tricyclic antidepressant may be associated with an increased VTE risk, but the quality of evidence was very low.
\end{abstract}

\section{INTRODUCTION}

Venous thromboembolism (VTE) comprises deep vein thrombosis (DVT) and pulmonary embolism (PE) (1). VTE may be fatal in the acute phase, and may lead to many long-term complications (2-4). Many risk factors for VTE have been identified, such as pregnancy, surgery, cancer and so on (1). VTE may also be associated with some drugs.

As the incidence of psychiatric disorders increases, the use of psychotropic drugs (antipsychotic drugs and antidepressant drugs) has increased dramatically (5-7). Two meta-analyses showed that antipsychotic drugs may be associated with an increased risk of VTE (without examine the relationship between antidepressant use and VTE risk) $(8,9)$; however, whether a relationship exists between antidepressant exposure and VTE is unclear. Some cases report the occurrence of VTE in patients with antidepressant use have been published in the past decade (10-12).

Some observational studies have been designed to evaluate the association between antidepressant and VTE; however, their results are controversial. Some of them found an association between antidepressant use and VTE risk $(13,14)$, whereas others not $(15,16)$. In addition, several studies indicated that different classes of antidepressant may be associated with different risk of VTE $(14,15)$.

The objective of this systematic review and metaanalysis was to examine the association between antidepressant use and the risk of VTE, and to ascertain the VTE risk associated with different type of antidepressant.

\section{METHODS}

\section{Search strategy}

A systematic search of Pubmed, Embase, and the Cochrane Library was conducted from inception to March 13, 2018, using the following combined Medical Subject Headings (MeSH) and free text words: (antidepressant or antidepressive or "monoamine oxidase inhibitors" or "serotonin reuptake inhibitors" or tricyclic or amitriptyline or clomipramine or dosulepin or dothiepin or doxepin or imipramine or maprotiline or amoxapine or desipramine or nortriptyline or protriptyline or trimipramine or lofepramine or moclobemide or

Corresponding Authors: Xiangli Cui (1484043795@qq.com) and Lihong Liu (liulihong@bjcyh.com), Department of Pharmacy, Beijing Chao-Yang Hospital, 8 Gongren Tiyuchang Nanlu, Chaoyang District, Beijing, China 
isocarboxazid or phenelzine or tranylcypromine or iproniazid or citalopram or escitalopram or fluoxetine or paroxetine or fluvoxamine or sertraline or venlafaxine or desvenlafaxine or duloxetine or milnacipran or levomilnacipran or trazodone or mirtazapine or nefazodone or vilazodone or bupropion or mianserin or tianeptine or viloxazine or maprotiline or agomelatine or vortioxetine or reboxetine) and (thromboembolism or "venous thromboembolism" or "venous thrombosis" or "pulmonary embolism" or "pulmonary thromboembolism" or "deep vein thrombosis"). In addition, the reference lists of included studies and review articles were screened for potential eligible studies. Included and excluded studies were collected following the Preferred Reporting Items for Systematic Reviews and Meta-Analyses (PRISMA) (17).

\section{Study selection}

Two reviewers independently performed the study selection, including screening titles and abstracts, and retrieving full texts of studies for details. Disagreements were resolved by discussion or through consultation with other authors. Casecontrol studies and cohort studies that examined the association between antidepressant use and the risk of VTE, DVT or PE were included. Only studies provided odds ratio (OR), risk ratio ( $\mathrm{RR})$, or hazard ratio (HR) with $95 \%$ confidence intervals $(\mathrm{CI})$, or provided data allowing the calculation of the estimate (OR, RR, or HR) and 95\% CI were included. No language restriction was applied.

\section{Data extraction and quality assessment}

Following information were extracted from the included studies: author name, year of publication, study design, data source, population, number of patients, definition of antidepressant exposure, outcomes, and adjusted/matched factors. Two reviewers independently assessed the risk of bias of included case-control studies and cohort studies using the Newcastle-Ottawa Scale (NOS) (18). Any discrepancies were addressed by consensus. NOS assess the quality of studies in three domains: selection, comparability, and exposure for casecontrol studies; and selection, comparability, and outcome for cohort studies. A maximum of nine stars can be received. Studies with nine stars on the NOS were judged to be at low risk of bias.

\section{Data synthesis and analysis}

The primary outcome was VTE. VTE comprises DVT and PE. For studies that reported only DVT or PE, data on DVT or PE was regarded as VTE for analysis. We also conducted analysis on PE. In order to explore the sources of heterogeneity, we conducted several subgroup analyses according to type of antidepressant (selective serotonin reuptake inhibitor (SSRI) vs. tricyclic antidepressant (TCA)), quality of study methodology (low risk of bias vs. high risk of bias) and type of study design (casecontrol studies vs. cohort studies). Sensitivity analyses were conducted by limiting meta-analysis to studies that only included depressed patients or studies that only included female patients. Sensitivity analysis that only included studies that have eliminated the effect of antipsychotics was also conducted.

When possible, adjusted estimates were used; otherwise, unadjusted estimates were calculated with raw data. Random effects model was used, as this takes into account any differences between studies even if there is no statistically significant heterogeneity. We assumed similarity between OR, RR, and HR because VTE and PE were rare events. Publication bias was assessed using Begg's funnel plot and Egger's test $(19,20)$. All statistical analyses were conducted using Stata 12.0.

The Grading of Recommendations Assessment, Development and Evaluation (GRADE) approach was used to assess the quality of evidence (21).

\section{RESULTS}

\section{Literature search}

Of a total of 1,531 records that were retrieved, 46 were duplicate records. After screening of the titles and abstracts, 1,428 records were excluded. After full text review of the remaining 57 records, 9 studies, including 6 case-control studies involving 40,831 patients $(14,15,22-25)$, and 3 cohort studies involving 900,562 patients $(13,16,26)$, were included in the final analysis (Figure 1).

\section{Characteristics of included studies}

Table 1 shows the characteristics of all the included studies. Of the 6 case-control studies, 2 were nested case-control studies, 2 were population based casecontrol studies, 1 was national case-control study and 1 was hospital based case-control study. 


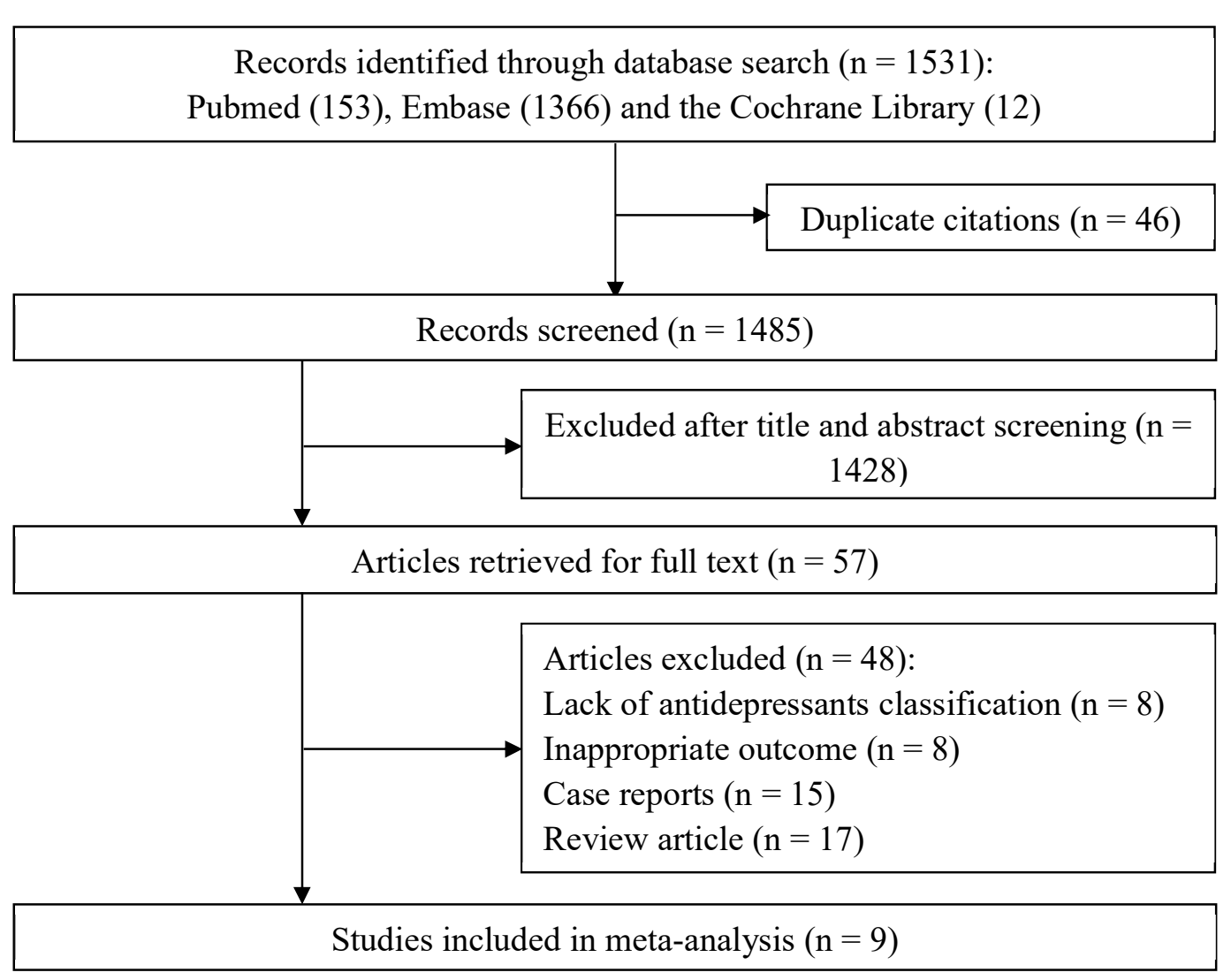

Figure 1. Flow chart depicting the selection process of studies included in the meta-analysis

Of the 3 cohort studies, 2 were retrospective cohort studies and 1 was prospective cohort study. Of these 9 included studies, 1 case-control study was designed to examine the relationship between corticosteroids exposure and VTE, while data on antidepressant use was also reported (24). One study which aimed to investigate the relationship between depression and VTE, evaluated the association between antidepressant and VTE in depressed patients (depressed patients with antidepressant vs. depressed patients without antidepressant) (16). One study only included female patients (13). The outcome measures were different among studies. Six studies reported data on VTE $(13-16,22,26), 3$ studies reported data on DVT $(13,25,26)$, and 3 studies reported data on PE (in 1 of these 3 studies, the outcome measure was fatal PE) $(13,23,24)$. All the 9 studies reported adjusted estimate.

Of the included studies, only 2 studies (1 casecontrol study (14) and 1 cohort study (26)) received nine stars on the NOS, indicating low risk of bias (Table 2 and Table 3). For case-control studies, stars were lost in comparability $(\mathrm{n}=4)$, selection of controls $(n=3)$, definition of the cases $(n=1)$, ascertainment of exposure $(n=1)$ (Table 2). For cohort studies, stars were lost in comparability $(\mathrm{n}=$ $1)$ and ascertainment of exposure $(n=1)$ (Table 3$)$.

\section{Antidepressant use and risk of VTE}

Figure 2 shows the association between antidepressant use and the risk of VTE of all included studies. Overall, the use of antidepressant significantly increased the risk of VTE ( 9 studies; OR $1.27,95 \%$ CI 1.09 to $1.49 ; \mathrm{I}^{2}=77.1 \%$ ). When we only included studies reported PE risk in the meta-analysis, the results shows that antidepressant use was associated with an increased risk of PE (3 studies; OR $1.50,95 \%$ CI 1.33 to $1.69 ; \mathrm{I}^{2}=15.9 \%$; Figure 3). In the subgroup analysis by quality of study methodology, a significant increased VTE risk with antidepressant use was observed in studies with high risk of bias (7 studies; OR 1.30, 95\% CI 1.12 to $1.51 ; \mathrm{I}^{2}=54.9 \%$; Figure 2 ), while no association observed in studies with low risk of bias (2 studies; OR $1.27,95 \%$ CI 0.84 to $1.92 ; I^{2}=91.1 \%$; Figure 2). 1 study reported the relationship between antidepressant use and VTE in depressed patients. The study showed there was no significant 
difference in the VTE risk between depressed patients with and without antidepressant use (OR $0.72,95 \%$ CI 0.39 to 1.31 ; Table 4 ). On the contrary, other studies showed that antidepressant use was associated with an increased VTE risk (8 studies; OR $1.31,95 \%$ CI 1.12 to $1.53 ; \mathrm{I}^{2}=77.9 \%$ ). Table 4 summarizes the results of subgroup analyses and sensitivity analyses. There was no publication bias (Begg's test $P=1.000$, Egger's test $P=0.576$ ). With GRADE approach, the quality of evidence was rated as very low because of risk of bias and inconsistency (Table 5).

\section{SSRI and risk of VTE}

Five studies evaluated the association between SSRI use and the risk of VTE. The results showed there was no significant difference in the VTE risk between patients with and without SSRI use (OR $1.10,95 \%$ CI 0.90 to $1.34 ; \mathrm{I}^{2}=62.3 \%$; Figure 4 ). Subgroup analysis by quality of study methodology did not change the results (studies with low risk of bias: OR $1.05,95 \%$ CI 0.94 to $1.18 ; \mathrm{I}^{2}=0.0 \%$; studies with high risk of bias: OR $1.05,95 \%$ CI 0.71 to $1.55 ; \mathrm{I}^{2}=73.5 \%$; Figure 4 ). No significant difference in the VTE risk between patients with and without SSRI was observed when we excluded the study with depressed patients (4 studies; OR 1.14, 95\% CI 0.93 to $1.40 ; \mathrm{I}^{2}=66.8 \%$ ). The study with depressed patients reported similar result (OR 0.75, $95 \%$ CI 0.40 to 1.38 ; Table 4 ). There was no publication bias (Begg's test $\mathrm{P}=1.000$, Egger's test $\mathrm{P}=0.799$ ). With GRADE approach, the quality of evidence was rated as very low because of risk of bias and inconsistency (Table 5).

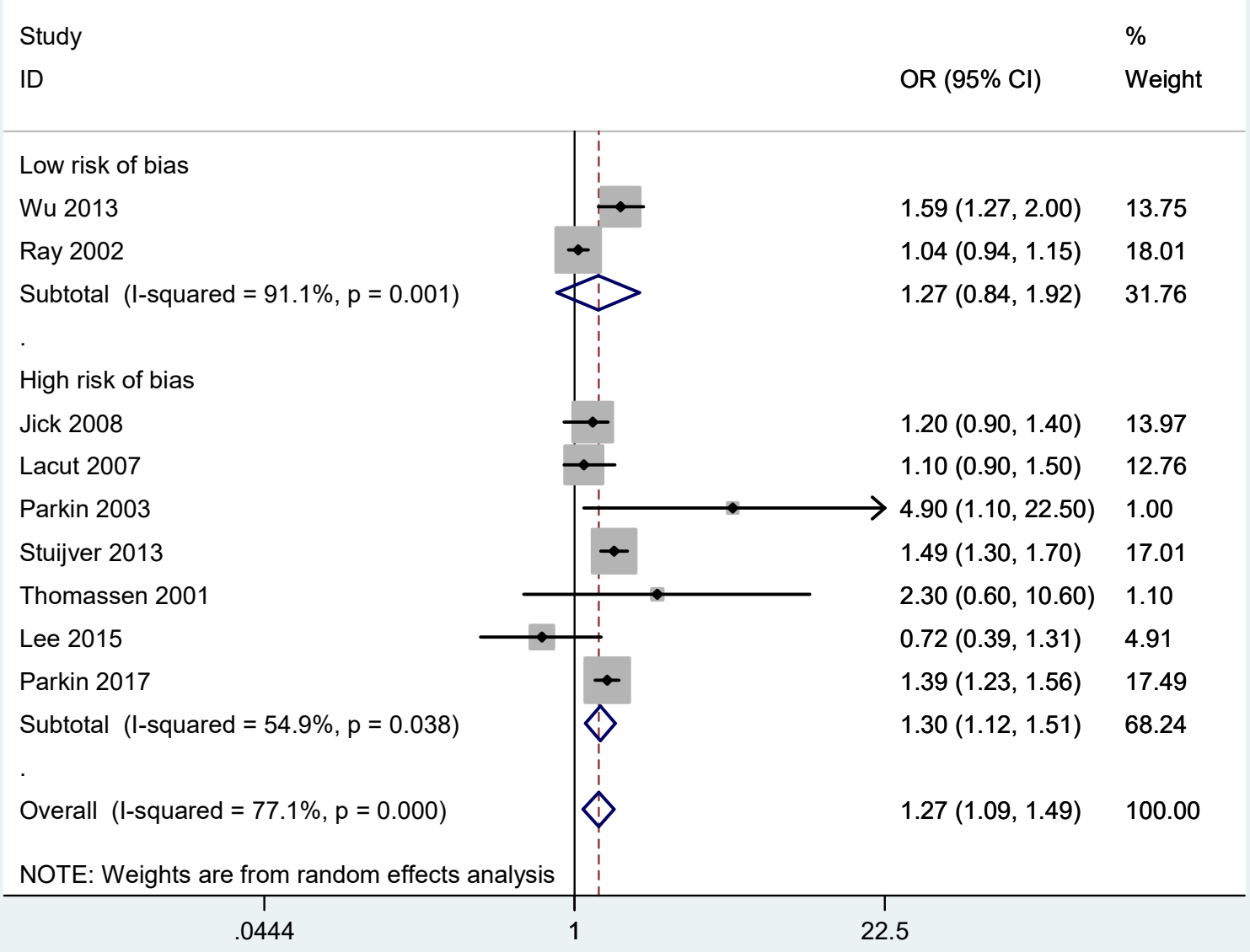

Figure 2. Association between antidepressant use and risk of VTE 
Study

ID
$\%$

OR $(95 \% \mathrm{Cl}) \quad$ Weight

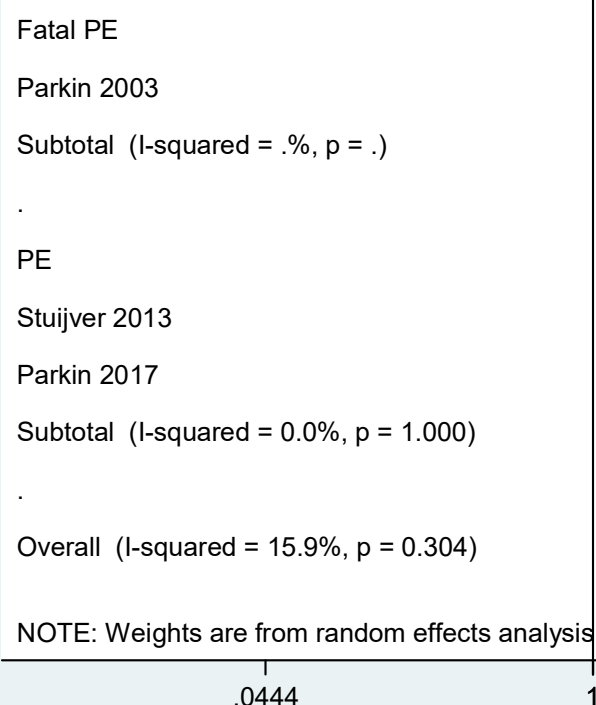

Figure 3. Association between antidepressant use and risk of PE

Study

ID

Low risk of bias

Wu 2013

Ray 2002

Subtotal (I-squared $=0.0 \%, p=0.475$ )

High risk of bias

Jick 2008

Lee 2015

Parkin 2017

Subtotal $($ I-squared $=73.5 \%, p=0.023)$

.

Overall $($ I-squared $=62.3 \%, p=0.031)$

NOTE: Weights are from random effects analysis
$\%$

OR $(95 \% \mathrm{Cl}) \quad$ Weight
$1.25(0.77,2.05) \quad 11.52$

$1.04(0.92,1.17) \quad 33.60$

$1.05(0.94,1.18) \quad 45.12$

$0.90(0.60,1.20) \quad 17.69$

$0.75(0.40,1.38) \quad 8.12$

$1.40(1.17,1.68) \quad 29.08$

$1.05(0.71,1.55) \quad 54.88$

$1.10(0.90,1.34) \quad 100.00$

Figure 4. Association between SSRI use and risk of VTE 


\section{TCA and risk of VTE}

Four studies evaluated the association between TCA use and the risk of VTE. The results showed that use of TCA was associated with an increased VTE risk (OR $1.26,95 \%$ CI 1.02 to $1.57 ; \mathrm{I}^{2}=79.1 \%$; Figure 5). In the subgroup analysis, a significant increased VTE risk with TCA exposure was observed in studies with high risk of bias ( 2 studies; OR 1.34, 95\% CI 1.17 to $1.54 ; \mathrm{I}^{2}=0.0 \%$; Figure 5), while no association observed in studies with low risk of bias (2 studies; OR $1.20,95 \%$ CI 0.77 to $1.89 ; \mathrm{I}^{2}=84.3 \%$; Figure 5). The study with depressed patients did not report the association between TCA use and VTE. There was no publication bias (Begg's test $\mathrm{P}=0.734$, Egger's test $\mathrm{P}=0.175$ ). With GRADE approach, the quality of evidence was rated as very low because of risk of bias and inconsistency (Table 5).

\section{DISCUSSION}

Our meta-analysis indicated that antidepressant use may be associated with an increased risk of VTE; however, no association was observed when we only included studies with low risk of bias and when we only included study with depressed patients. No association between SSRI use and VTE risk was detected in the overall analysis and in the subgroup analysis by quality of study methodology. A significant increased VTE risk with TCA use was observed, and the quality of evidence was rated as very low. However, no association between TCA use and VTE risk was observed when we only included studies with low risk of bias and when we only included studies that have eliminate the effect of antipsychotics.

A significant increased VTE risk was detected with antidepressant use, and the quality of evidence was rated as very low by GRADE approach. However, no association was detected when we only included studies with low risk of bias. Such phenomenon was also observed in the TCA group. Only 2 studies were judged to be at low risk of bias. When we pooled the data from these 2 studies with low risk of bias, high heterogeneity was detected (antidepressant: $\mathrm{I}^{2}=91.1 \%$; TCA: $\mathrm{I}^{2}=84.3 \%$ ), which lead the quality of evidence was rated down by GRADE approach. The heterogeneity can be partly explained by the different type of study design. Of these 2 studies with low risk of bias, 1 was casecontrol study and 1 was cohort study. Compared with cohort studies, case-control studies may reflect relatively short-term effects of antidepressant exposure (27). In addition, the duration of antidepressant use may also different between casecontrol studies and cohort studies.

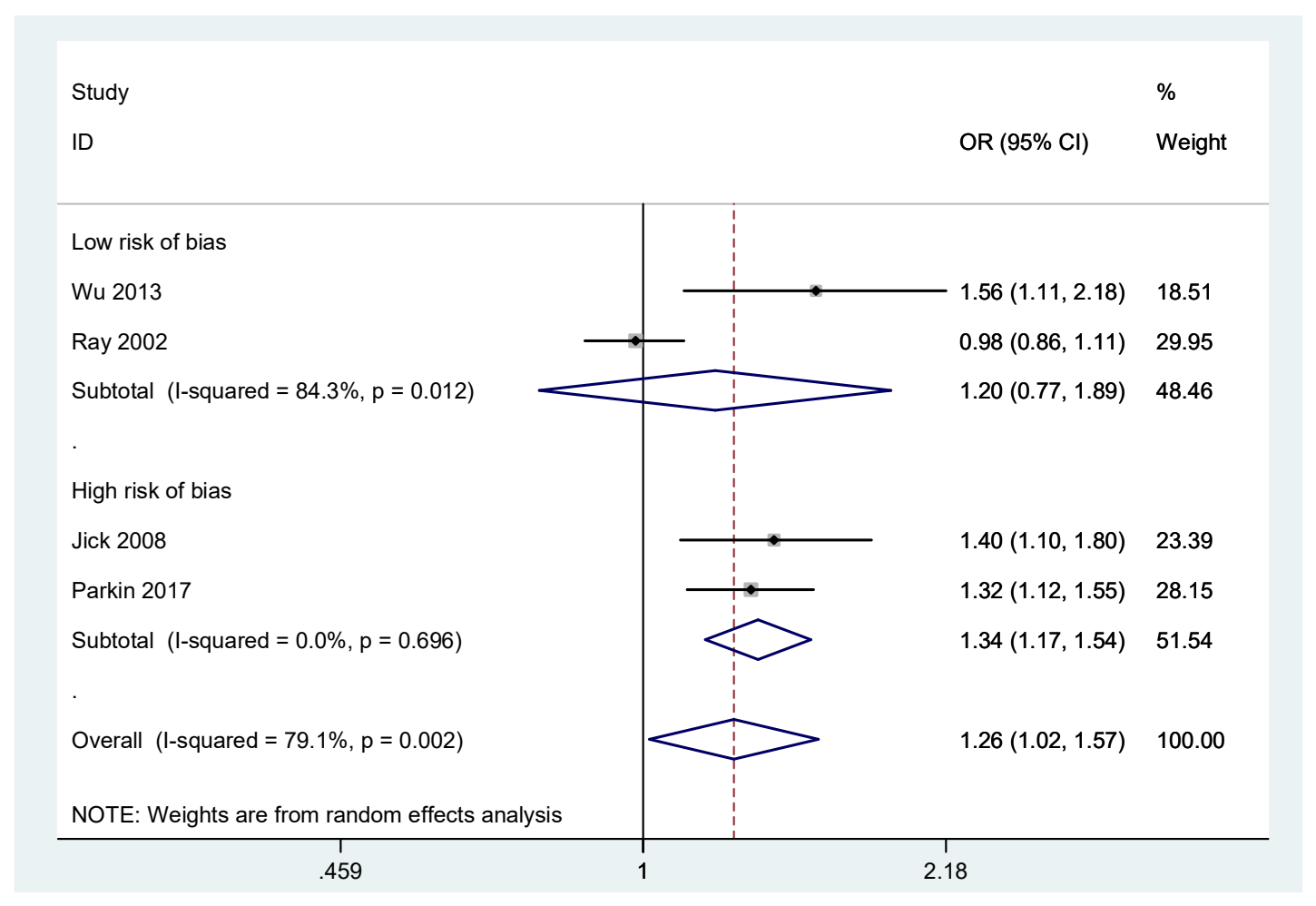

Figure 5. Association between TCA use and risk of VTE 
Several previous studies observed a significant increased risk of VTE in depressed patients (28-30); however, it is unclear whether depression, antidepressant use or even another related factor drove the increased VTE risk (31). In our metaanalysis, an increased VTE risk with antidepressant use was detected; whereas, sensitivity analysis that only included study with depressed patients failed to detect an association between antidepressant use and VTE risk. Because most of the antidepressant drugs were prescribed for depression treatment and most patients without antidepressant use were nondepressed patients, these data seem to indicate that increased VTE risk may actually be associated with the depression itself but not the antidepressant use.

Interestingly, in the subgroup analyses of our study, we found that the relationship between antidepressant use and VTE risk varied according to the type of antidepressant exposure. Increased VTE risk was detected in TCA use group, but not in SSRI use group. The data did not support the previous hypothesis that depression lead to the increased VTE risk. If it is the depression drove the increased VTE risk, the VTE risk would not be changed according to the type of antidepressant. Serotonin is a weak platelet agonist and serotonin potentiates platelet stimulation induced by adenosine diphosphate or thrombin (32). SSRI decrease serotonin level in platelets by inhibiting serotonin reuptake; therefore, SSRI may relate to decreased platelet activation and prolongation of bleeding time (32). This view may explain why SSRI use did not associate with an increased VTE risk. In fact, a systematic review suggested that SSRI may be associated with increased perioperative bleeding events (33). Systematic reviews showed that antipsychotic drugs may be associated with an increased risk of VTE $(8,9)$. As for the first-generation antipsychotics, the OR was $1.74,95 \%$ CI 1.28-2.37 (8) and 1.72, $95 \%$ CI 1.31-2.24 (9) in these two systematic reviews, respectively. The chemical structure of the TCA is similar to that of the phenothiazines, one kind of the first-generation antipsychotics (14). This view may explain why TCA use increased VTE risk.

Although another meta-analysis examined the association between antidepressant use and the risk of VTE has been published (34), the findings from our manuscript differ from that paper. The previous meta-analysis showed that both TCA and SSRI were associated with an increased VTE risk, however no association between SSRI use and VTE risk was detected in our manuscript. The previous metaanalysis only included 6 studies compared patients with antidepressant versus individuals without antidepressant, so 1 study with data about SSRI was not included into analysis. In addition, fix effects model was used in the previous meta-analysis, although high heterogeneity was found.

The strengths of this study included the comprehensive literature search, critical appraisal of the included studies, planned subgroup analyses and sensitivity analyses, and the use of GRADE approach. However, our meta-analysis has several limitations. First, only observational studies were included in our meta-analysis. No randomized control trial addressing antidepressant use and its effect on VTE have been published. VTE is associated with a lot of risk factors. Although the included studies attempted to minimize the effect of other risk factors, possibly none of them could fully adjust for all these risk factors. This is the reason why we did not conducted sensitivity analysis on idiopathic VTE. Second, the heterogeneity is relatively high in our meta-analysis. There are many differences between the included studies, such as the definition of antidepressant exposure, age and gender of the patients, and so on. We largely divided antidepressants into TCA and SSRI; however, some studies had different categories $(14,15)$. Third, only 9 studies were included and only 2 studies were judged to be at low risk of bias. The number of studies on this topic limited the possibility of further analysis. More high-quality studies examining the relationship between antidepressant use and VTE risk are needed.

\section{CONCLUSIONS}

In conclusion, our meta-analysis suggested that there was no association between selective serotonin reuptake inhibitor use and venous thromboembolism risk in the overall analysis and in subgroup analysis of studies with low risk of bias. Tricyclic antidepressant may be associated with an increased venous thromboembolism risk, but the quality of evidence was rated as very low. However, no association between tricyclic antidepressant use and venous thromboembolism risk was observed when we only included studies with low risk of bias.

\section{CONFLICTS OF INTEREST}

The author(s) declared no conflicts of interest.

\section{ACKNOWLEDGEMENTS}

Not applicable. 


\section{REFERENCES}

1. Konstantinides SV, Torbicki A, Agnelli G, Danchin N, Fitzmaurice D, Galie N, et al. 2014 ESC guidelines on the diagnosis and management of acute pulmonary embolism. Eur Heart J, 2014; 35:3033-3069, 3069a-3069k.

2. Fanikos J, Piazza G, Zayaruzny M, Goldhaber SZ. Long-term complications of medical patients with hospital-acquired venous thromboembolism. Thromb Haemost, 2009; 102:688-693.

3. Klok FA, van Kralingen KW, van Dijk AP, Heyning FH, Vliegen HW, Kaptein AA, et al. Quality of life in long-term survivors of acute pulmonary embolism. Chest, 2010; 138:1432-1440.

4. Sogaard KK, Schmidt M, Pedersen L, Horvath-Puho E, Sorensen HT. 30-year mortality after venous thromboembolism: a population-based cohort study. Circulation, 2014; 130:829-836.

5. Kessler RC, Angermeyer M, Anthony JC, R DEG, Demyttenaere $\mathrm{K}$, Gasquet $\mathrm{I}$, et al. Lifetime prevalence and age-of-onset distributions of mental disorders in the World Health Organization's World Mental Health Survey Initiative. World Psychiatry, 2007; 6:168-176.

6. Pedersen CB, Mors O, Bertelsen A, Waltoft BL, Agerbo E, McGrath JJ, et al. A comprehensive nationwide study of the incidence rate and lifetime risk for treated mental disorders. JAMA psychiatry, 2014; 71:573-581.

7. Reid S, Barbui C. Long term treatment of depression with selective serotonin reuptake inhibitors and newer antidepressants. BMJ, 2010; 340:c1468.

8. Barbui C, Conti V, Cipriani A. Antipsychotic drug exposure and risk of venous thromboembolism: a systematic review and meta-analysis of observational studies. Drug safety, 2014; 37:79-90.

9. Zhang R, Dong L, Shao F, Tan X, Ying K. Antipsychotics and venous thromboembolism risk: a meta-analysis. Pharmacopsychiatry, 2011; 44:183188.

10. Kurne A, Ertugrul A, Anil Yagcioglu AE, Yazici KM. Venous thromboembolism and escitalopram. General hospital psychiatry, 2004; 26:481-483.

11. Mari F, Gualco B, Rensi R, Bertol E. Acute massive pulmonary thromboembolism due to acute intoxication by duloxetine: a case report. Cardiovascular toxicology, 2012; 12:258-262.

12. Singer L, Finance F, Ruh D. Pulmonary embolism occurring within a month in 3 elderly women suffering from manic depressive psychosis. Discussion. Pathogenic role of the psychiatric treatment. Annales medico-psychologiques, 1975; 133 I:256-263.

13. Parkin L, Balkwill A, Sweetland S, Reeves GK, Green J, Beral V. Antidepressants, Depression, and Venous Thromboembolism Risk: Large Prospective Study of UK Women. Journal of the American Heart Association, 2017; 6.
14. Wu CS, Chang CM, Chen CY, Wu EC, Wu KY, Liang HY, et al. Association between antidepressants and venous thromboembolism in Taiwan. J Clin Psychopharmacol, 2013; 33:31-37.

15. Jick SS, Li L. Antidepressant drug use and risk of venous thromboembolism. Pharmacotherapy, 2008; 28:144-150.

16. Lee CW, Liao CH, Lin CL, Liang JA, Sung FC, Kao $\mathrm{CH}$. Depression and risk of venous thromboembolism: a population-based retrospective cohort study. Psychosom Med, 2015; 77:591-598.

17. Moher D, Liberati A, Tetzlaff J, Altman DG. Preferred reporting items for systematic reviews and meta-analyses: the PRISMA statement. Annals of internal medicine, 2009; 151:264-269, W264.

18. Wells GS, B; O'Connell, D; Peterson, J; Welch, V; Losos, M; Tugwell, P;. The NewcastleOttawa Scale (NOS) for assessing the quality of nonrandomised studies in meta-analyses. 2005.

19. Begg CB, Mazumdar M. Operating characteristics of a rank correlation test for publication bias. Biometrics, 1994; 50:1088-1101.

20. Egger M, Davey Smith G, Schneider M, Minder C. Bias in meta-analysis detected by a simple, graphical test. BMJ (Clinical research ed), 1997; 315:629-634.

21. Guyatt GH, Oxman AD, Vist GE, Kunz R, FalckYtter Y, Alonso-Coello P, et al. GRADE: an emerging consensus on rating quality of evidence and strength of recommendations. BMJ (Clinical research ed), 2008; 336:924-926.

22. Lacut K, Le Gal G, Couturaud F, Cornily G, Leroyer C, Mottier D, et al. Association between antipsychotic drugs, antidepressant drugs and venous thromboembolism: results from the EDITH case-control study. Fundamental \& clinical pharmacology, 2007; 21:643-650.

23. Parkin L, Skegg DCG, Herbison GP, Paul C. Psychotropic drugs and fatal pulmonary embolism. Pharmacoepidemiology and drug safety, 2003; 12:647-652.

24. Stuijver DJF, Majoor CJ, Van Zaane B, Souverein PC, De Boer A, Dekkers OM, et al. Use of oral glucocorticoids and the risk of pulmonary embolism: A population-based case-control study. Chest, 2013; 143:1337-1342.

25. Thomassen R, Vandenbroucke JP, Rosendaal FR. Antipsychotic medication and venous thrombosis. British Journal of Psychiatry, 2001; 178:63-66.

26. Ray JG, Mamdani MM, Yeo EL. Antipsychotic and antidepressant drug use in the elderly and the risk of venous thromboembolism. Thrombosis and haemostasis, 2002; 88:205-209.

27. Oh SW, Kim J, Myung SK, Hwang SS, Yoon DH. Antidepressant use and risk of coronary heart disease: meta-analysis of observational studies. Br J Clin Pharmacol, 2014; 78:727-737.

28. Enga KF, Braekkan SK, Hansen-Krone IJ, Hansen JB. Emotional states and future risk of venous thromboembolism: the Tromso Study. Thromb 
Haemost, 2012; 107:485-493.

29. Rosengren A, Freden M, Hansson PO, Wilhelmsen L, Wedel H, Eriksson H. Psychosocial factors and venous thromboembolism: a long-term follow-up study of Swedish men. J Thromb Haemost, 2008; 6:558-564.

30. Austin AW, Wissmann T, von Kanel R. Stress and hemostasis: an update. Semin Thromb Hemost, 2013; 39:902-912.

31. Branchford BR. Venous thromboembolism risk with antidepressants: Driven by disease or drugs? Journal of the American Heart Association, 2017; 6.

32. Dietrich-Muszalska A, Wachowicz B. Platelet haemostatic function in psychiatric disorders: Effects of antidepressants and antipsychotic drugs. The world journal of biological psychiatry : the official journal of the World Federation of Societies of Biological Psychiatry, 2017; 18:564-574.

33. Mahdanian AA, Rej S, Bacon SL, Ozdin D, Lavoie KL, Looper K. Serotonergic antidepressants and perioperative bleeding risk: a systematic review. Expert opinion on drug safety, 2014; 13:695-704.

34. Kunutsor SK, Seidu S, Khunti K. Depression, antidepressant use, and risk of venous thromboembolism: systematic review and metaanalysis of published observational evidence. Annals of Medicine, 2018. 
Table 1. Characteristics of included observational studies

\begin{tabular}{|c|c|c|c|c|c|c|c|}
\hline Study & Design, years & $\begin{array}{l}\text { Data Sources, } \\
\text { country }\end{array}$ & Population & Category & $\begin{array}{c}\text { Definition of antidepressant } \\
\text { exposure }\end{array}$ & $\begin{array}{l}\text { Outcomes, } \\
\text { follow up }\end{array}$ & Controlled variables \\
\hline $\begin{array}{ll}\text { Jick } & 2008 \\
(15) & \end{array}$ & $\begin{array}{l}\text { Nested case- } \\
\text { control study, } \\
\text { from January } 1, \\
1990 \text { to } \\
\begin{array}{l}\text { December } \\
2005\end{array}\end{array}$ & $\begin{array}{l}\text { United } \\
\text { Kingdom } \\
\text { General } \\
\text { Practice } \\
\text { Research } \\
\text { Database, the } \\
\text { United } \\
\text { Kingdom }\end{array}$ & $\begin{array}{l}\text { Inclusion criteria: patients aged } 70 \text { years } \\
\text { or younger. } \\
\text { Exclusion criteria: patients with a history } \\
\text { of trauma, surgery, or pregnancy within } \\
\text { the } 3 \text { months before the index date; } \\
\text { patients with stroke, MI or angina, } \\
\text { cerebrovascular disease, epilepsy, RF, } \\
\text { insulin-dependent DM, cancer, drug } \\
\text { abuse or alcohol abuse any time before } \\
\text { the index date; patients with a history of } \\
\text { anticoagulation therapy more than } 60 \\
\text { days before the index date. }\end{array}$ & $\begin{array}{l}\text { Total: } 3867 \\
\text { Case: } 782 \text { (current use of } \\
\text { antidepressant: 141, } \\
\text { recent use of } \\
\text { antidepressant: } 23 \text { ) } \\
\text { Control: } 3085 \text { (current } \\
\text { use of antidepressant: } \\
497 \text {, recent use of } \\
\text { antidepressant: } 67 \text { ) }\end{array}$ & $\begin{array}{l}\text { Computerized data. } \\
\text { Current use of antidepressant is } \\
\text { defined as having the last } \\
\text { prescription issued within the } 60 \\
\text { days before the index date. Recent } \\
\text { use of antidepressant is defined as } \\
\text { having last prescription issued } \\
\text { within 61-90 days before the index } \\
\text { date. }\end{array}$ & $\begin{array}{l}\text { Idiopathic } \\
\text { VTE }\end{array}$ & $\begin{array}{l}\text { Controls were matched } \\
\text { according to age, sex, } \\
\text { practice attended, index } \\
\text { date, and duration of } \\
\text { computerized medical } \\
\text { record. No association } \\
\text { between antipsychotic use } \\
\text { and VTE. } \\
\text { Case patients had the higher } \\
\text { BMI than control patients, } \\
\text { however, only data for } \\
\text { amitriptyline adjusted for } \\
\text { BMI using conditional } \\
\text { logistic regression analysis. }\end{array}$ \\
\hline $\begin{array}{l}\text { Lacut } \\
2007(22)\end{array}$ & $\begin{array}{l}\text { Hospital based } \\
\text { case-control } \\
\text { study, from May } \\
2000 \text { to } \\
\text { December } 2004\end{array}$ & $\begin{array}{l}\text { The EDITH } \\
\text { study, Brest } \\
\text { University } \\
\text { Hospital, } \\
\text { France }\end{array}$ & $\begin{array}{l}\text { Inclusion criteria: aged over } 18 \text { years } \\
\text { hospitalized patients without major } \\
\text { acquired risk factor for VTE. } \\
\text { Exclusion criteria: patients with active } \\
\text { malignancy, surgery or plaster cast in the } \\
\text { past } 3 \text { months, pregnancy or delivery in } \\
\text { the past } 3 \text { months. }\end{array}$ & $\begin{array}{l}\text { Total: 1354 } \\
\text { Case: } \\
\text { (antidepressant: 135) } \\
\text { Control: } \\
\text { (antidepressant: 123) }\end{array}$ & $\begin{array}{l}\text { One-to-one interview. If available, } \\
\text { charts and medical records were } \\
\text { reviewed. } \\
\text { For outpatients, exposure was } \\
\text { defined as current use of drugs at } \\
\text { admission. All drugs recorded had to } \\
\text { be taken at admission for more than } \\
1 \text { week. Drugs taken prior to } \\
\text { admission but discontinued more } \\
\text { than } 1 \text { week before admission were } \\
\text { not recorded. For inpatients, all } \\
\text { drugs taken at the time of inclusion } \\
\text { were recorded, including drugs } \\
\text { prescribed in hospital. }\end{array}$ & $\mathrm{E}$ & $\begin{array}{l}\text { Controls were matched } \\
\text { according to age and sex. } \\
\text { However, without adjusted } \\
\text { for BMI, factor V Leiden } \\
\text { and prothrombin G20210A } \\
\text { gene variation. }\end{array}$ \\
\hline $\begin{array}{l}\text { Parkin } \\
2003 \text { (23) }\end{array}$ & $\begin{array}{l}\text { National case- } \\
\text { control study, } \\
\text { from January } 1 \text {, }\end{array}$ & $\begin{array}{l}\text { Coroners' and } \\
\text { police records, } \\
\text { death }\end{array}$ & $\begin{array}{l}\text { Inclusion criteria: New Zealand patients } \\
\text { aged } 15-59 \text { years without major risk } \\
\text { factors for VTE. }\end{array}$ & $\begin{array}{l}\text { Total: } 263 \\
\text { Case: } 54 \text { (antidepressant: } \\
\text { 6) }\end{array}$ & $\begin{array}{l}\text { Records of general practitioners, } \\
\text { family planning clinics and } \\
\text { psychiatric services. }\end{array}$ & Fatal PE & $\begin{array}{lr}\text { Controls were } & \text { matched } \\
\text { according to age } & \text { and sex. } \\
\text { Conditional } & \text { logistic }\end{array}$ \\
\hline
\end{tabular}


1990 to certificates Exclusion criteria: patients with history of Control:

December 31, and hospital VTE or of prolonged immobility, severe (antidepressant: 7)

1998 injury, major surgery or pregnancy during the 2 months before the index date were excluded.
209 Users of psychotropic drugs were defined as those who had been prescribed medication for at least 1 month. Current use was defined as prescribed use at any time during the 3 months before the index date. regression adjusted for weight, combined oral contraceptive use and hormone replacement therapy during the 3 months before the index date. Current users of antipsychotics

excluded.

\begin{tabular}{|c|c|c|c|c|c|c|c|}
\hline $\begin{array}{l}\text { Stuijver } \\
2013(24)\end{array}$ & $\begin{array}{l}\text { Population } \\
\text { based case- } \\
\text { control study, } \\
\text { from } 1998 \text { to } \\
2008\end{array}$ & $\begin{array}{l}\text { PHARMO } \\
\text { Record } \\
\text { Linkage } \\
\text { System, } \\
\text { Netherlands }\end{array}$ & $\begin{array}{l}\text { Inclusion criteria: patients aged } 18 \text { years } \\
\text { or older. } \\
\text { Exclusion criteria: patients with history of } \\
\text { PE. }\end{array}$ & $\begin{array}{l}\text { Total: } 21297 \\
\text { Case: } \\
\text { (antidepressant: } 328 \text { ) } \\
\text { Control: } \quad 16802 \\
\text { (antidepressant: } 844 \text { ) } \\
\end{array}$ & $\begin{array}{l}\text { Database. } \\
\text { Use of antidepressant is defined as } \\
\text { having the prescription issued } \\
\text { within } 3 \text { months period prior to the } \\
\text { index date. }\end{array}$ & PE & $\begin{array}{l}\text { Controls were matched } \\
\text { according to age, sex and } \\
\text { index date. }\end{array}$ \\
\hline $\begin{array}{l}\text { Thomasse } \\
\mathrm{n} \quad 2001 \\
(25)\end{array}$ & $\begin{array}{l}\text { Population } \\
\text { based case- } \\
\text { control study, } \\
\text { from } 1990 \text { to } \\
1993\end{array}$ & $\begin{array}{l}\text { Leiden } \\
\text { Thrombophilia } \\
\text { Study, } \\
\text { Netherlands }\end{array}$ & $\begin{array}{l}\text { Exclusion criteria: patients aged } 70 \text { years } \\
\text { or older; patients with malignancies; } \\
\text { psychiatric in-patients or general hospital } \\
\text { in-patients; patients with a history of } \\
\text { VTE. }\end{array}$ & $\begin{array}{l}\text { Total: } 948 \\
\text { Case: } \\
\text { (antidepressant: } 8 \text { ) } \\
\text { Control: } \\
\text { (antidepressant: } 3 \text { ) }\end{array}$ & $\begin{array}{l}\text { Records. } \\
\text { Use of antidepressants prior to the } \\
\text { first thrombosis. }\end{array}$ & DVT & $\begin{array}{l}\text { Controls were matched } \\
\text { according to age and sex. }\end{array}$ \\
\hline $\begin{array}{l}\text { Wu } 2013 \\
(14)\end{array}$ & $\begin{array}{l}\text { Nested case- } \\
\text { control study, } \\
\text { from } 2001 \text { to } \\
2009\end{array}$ & $\begin{array}{l}\text { Longitudinal } \\
\text { Health } \\
\text { Insurance } \\
\text { Database } \\
\text { 2005, Taiwan }\end{array}$ & $\begin{array}{l}\text { Inclusion criteria: patients aged } 18 \text { years } \\
\text { or older. } \\
\text { Exclusion criteria: patients who already } \\
\text { had a prior diagnosis of VTE. }\end{array}$ & $\begin{array}{l}\text { Total: } 13102 \\
\text { Case: } \quad 1880 \\
\text { (antidepressant: } 162 \text { ) } \\
\text { Control: } \quad 11222 \\
\text { (antidepressant: } 397 \text { ) }\end{array}$ & $\begin{array}{l}\text { Prescription claim data. } \\
\text { Current users were defined as those } \\
\text { who had been prescribed at least } 1 \\
\text { day of antidepressant drug supply } \\
\text { during the month before the index } \\
\text { date. }\end{array}$ & VTE & $\begin{array}{l}\text { Controls were matched } \\
\text { according to age and sex. } \\
\text { Conditional } \\
\text { regressions adjusted for } \\
\text { disease risk score } \\
\text { (comorbid medical and } \\
\text { psychiatric } \\
\text { medications, and health } \\
\text { care use). }\end{array}$ \\
\hline $\begin{array}{l}\text { Lee } 2015 \\
(16)\end{array}$ & $\begin{array}{l}\text { Retrospective } \\
\text { cohort study, } \\
\text { from } 2000 \text { to } \\
2011\end{array}$ & $\begin{array}{l}\text { Longitudinal } \\
\text { Health } \\
\text { Insurance } \\
\text { Database } \\
\text { 2010, Taiwan }\end{array}$ & $\begin{array}{l}\text { Inclusion criteria: newly diagnosed } \\
\text { depressed patients. } \\
\text { Exclusion criteria: patients with VTE } \\
\text { before index date, aged } 20 \text { years or } \\
\text { younger and missing information about }\end{array}$ & $\begin{array}{l}\text { Depressed patients: } \\
35274 \\
\text { SSRI: } 18177 \text { (VTE: 68) } \\
\text { Non-SSRI: } 7634 \text { (VTE: } \\
\text { 30) }\end{array}$ & Pres & $\begin{array}{l}\text { VTE; } \\
\text { Follow-up } \\
\text { until } \\
\text { diagnosis of } \\
\text { VTE or the }\end{array}$ & $\begin{array}{l}\text { Multivariate } \\
\text { proportional hox } \\
\text { regression. Adjusted with } \\
\text { age, sex, and the } \\
\text { comorbidities, namely, AF, }\end{array}$ \\
\hline
\end{tabular}


age or sex.

\begin{tabular}{|c|c|c|c|c|c|c|c|}
\hline & & & age or sex. & $\begin{array}{l}\text { Atypical antipsychotics: } \\
7133 \text { (VTE: } 30 \text { ) } \\
\text { Without antidepressant: } \\
2330 \text { (VTE: } 12 \text { ) }\end{array}$ & & end of 2011 & $\begin{array}{l}\text { hypertension, diabetes, } \\
\text { CVA, HF. Not adjusted with } \\
\text { lower leg fracture or } \\
\text { operations, and cancers. }\end{array}$ \\
\hline $\begin{array}{l}\text { Parkin } \\
2017 \text { (13) }\end{array}$ & $\begin{array}{l}\text { Prospective } \\
\text { cohort study, } \\
\text { from } 1996 \text { to } \\
2001\end{array}$ & $\begin{array}{l}\text { The Million } \\
\text { Women Study, } \\
\text { the National } \\
\text { Health Service } \\
\text { Breast } \\
\text { Screening } \\
\text { Programme, } \\
\text { England and } \\
\text { Scotland }\end{array}$ & $\begin{array}{l}\text { Inclusion criteria: women included in the } \\
\text { National Health Service Breast Screening } \\
\text { Programme. } \\
\text { Exclusion criteria: women who have prior } \\
\text { VTE, cancer, or recent surgery. }\end{array}$ & $\begin{array}{l}\text { Total: } 734092 \\
\text { Antidepressant: } 50354 \\
\text { (VTE: 313) } \\
\text { Other psychotropic } \\
\text { drugs: 19468 (VTE: 137) } \\
\text { Treatment/no drugs: } \\
\text { 13563 (VTE: 79) } \\
\text { No treatment/no drugs } \\
\text { (referent): } 650707 \text { (VTE: } \\
\text { 3393) }\end{array}$ & $\begin{array}{l}\text { Questionnaire, medications used } \\
\text { during most of the last } 4 \text { weeks. } \\
\text { Women were classified as } \\
\text { antidepressant users if they ticked } \\
\text { the amitriptyline or Prozac boxes, or } \\
\text { if they recorded the names of other } \\
\text { antidepressants. }\end{array}$ & $\begin{array}{l}\text { VTE, PE, } \\
\text { DVT; } \\
\text { average of } \\
7.3 \mathrm{y}\end{array}$ & $\begin{array}{l}\text { Cox regression analyses. } \\
\text { Adjusted with age, BMI, } \\
\text { smoking, alcohol } \\
\text { consumption, frequency of } \\
\text { strenuous physical activity, } \\
\text { hormone therapy, DM, high } \\
\text { BP, and socioeconomic } \\
\text { status, and stratified by } \\
\text { recruitment region. }\end{array}$ \\
\hline $\begin{array}{ll}\text { Ray } & 2002 \\
(26) & \end{array}$ & $\begin{array}{l}\text { Retrospective } \\
\text { cohort study, } \\
\text { from January 1, } \\
1994 \text { to March } \\
\text { 31, } 2000\end{array}$ & $\begin{array}{l}\text { Linked health } \\
\text { care } \\
\text { administrative } \\
\text { databases of } \\
\text { Ontario, } \\
\text { Canada }\end{array}$ & $\begin{array}{l}\text { Inclusion criteria: patients aged } 65 \text { years } \\
\text { or older. } \\
\text { Exclusion criteria: patients with a } \\
\text { diagnosis of cancer, DVT, PE within } 36 \\
\text { months prior to study entry, or patients } \\
\text { had been prescribed warfarin within } 12 \\
\text { months prior to study entry. }\end{array}$ & $\begin{array}{l}\text { Total: } 131196 \\
\text { Antidepressant: } \\
\text { (DVT: } 11.6 \text { per } 1000 \\
\text { person-years) } \\
\text { Antipsychotics: } 22514 \\
\text { (DVT: 16.5 per } 1000 \\
\text { person-years) } \\
\text { Thyroid replacement } \\
\text { hormones (referent): } \\
33033 \text { (DVT: } 10.1 \text { per } \\
\text { 1000 person-years) }\end{array}$ & $\begin{array}{l}\text { Database. } \\
\text { Had a prescription for a study drug } \\
\text { between January } 1,1994 \text { through } \\
\text { January } 31,2000 \text {; had not filled a } \\
\text { prescription for another study drug } \\
\text { within } 365 \text { days of the current study } \\
\text { drug; and had filled at least two } \\
\text { prescriptions for the current study } \\
\text { drug within } 180 \text { days of its initiation }\end{array}$ & $\begin{array}{l}\text { DVT, VTE; } \\
\text { follow-up } \\
\text { until March } \\
31,2000\end{array}$ & $\begin{array}{l}\text { Cox proportional hazards } \\
\text { regression model. Adjusted } \\
\text { with age, sex, current } \\
\text { residing within a long-term } \\
\text { care facility, recent prior } \\
\text { hospitalization, newly } \\
\text { diagnosed cancer or } \\
\text { concurrent prescription of } \\
\text { lithium, estrogen, aspirin or } \\
\text { warfarin. }\end{array}$ \\
\hline
\end{tabular}

$\mathrm{MI}=$ myocardial infarction; $\mathrm{RF}=$ renal failure; $\mathrm{DM}=$ diabetes mellitus; $\mathrm{VTE}=$ venous thromboembolism; $\mathrm{BMI}=$ body mass index; EDITH $=$ Etude des De'terminants et Interaction de la THrombose veineuse; $\mathrm{PE}=$ pulmonary embolism; $\mathrm{SSRI}=$ selective serotonin reuptake inhibitor; $\mathrm{AF}=$ atrial fibrillation; $\mathrm{CVA}=$ cerebral vascular accident; $\mathrm{HF}$ $=$ heart failure; $\mathrm{DVT}=$ deep vein thrombosis; $\mathrm{BP}=$ blood pressure. 
Table 2. Risk of bias of included case-control studies

\begin{tabular}{|c|c|c|c|c|c|c|c|c|}
\hline \multirow[b]{2}{*}{ Study } & \multicolumn{4}{|c|}{ Selection } & \multirow[b]{2}{*}{ Comparability } & \multicolumn{3}{|c|}{ Exposure } \\
\hline & $\begin{array}{c}\text { Adequate case } \\
\text { definition }\end{array}$ & $\begin{array}{c}\text { Representativeness of } \\
\text { the cases }\end{array}$ & $\begin{array}{l}\text { Selection of } \\
\text { controls }\end{array}$ & $\begin{array}{l}\text { Definition of } \\
\text { controls }\end{array}$ & & $\begin{array}{l}\text { Ascertainment of } \\
\text { exposure }\end{array}$ & $\begin{array}{l}\text { Same method of } \\
\text { ascertainment for } \\
\text { cases and controls }\end{array}$ & $\begin{array}{l}\text { Non-response } \\
\text { rate }\end{array}$ \\
\hline Jick 2008 (15) & $*$ & $*$ & $*$ & $*$ & $*$ & $*$ & $*$ & $*$ \\
\hline Lacut 2007 (22) & * & $*$ & & $*$ & $*$ & & $*$ & $*$ \\
\hline Parkin 2003 (23) & $*$ & $*$ & & $*$ & $* *$ & $*$ & $*$ & $*$ \\
\hline Stuijver 2013 (24) & & $*$ & $*$ & $*$ & $*$ & $*$ & $*$ & $*$ \\
\hline Thomassen 2001 (25) & $*$ & $*$ & & $*$ & $*$ & $*$ & $*$ & $*$ \\
\hline Wu 2013 (14) & $*$ & $*$ & $*$ & $*$ & $* *$ & $*$ & $*$ & $*$ \\
\hline
\end{tabular}

A study can receive a maximum of one star for each item within the Selection and Exposure categories and two stars for Comparability.

Table 3. Risk of bias of included cohort studies

\begin{tabular}{|c|c|c|c|c|c|c|c|c|}
\hline \multirow[b]{2}{*}{ Study } & \multicolumn{4}{|c|}{ Selection } & \multirow[b]{2}{*}{ Comparability } & \multicolumn{3}{|c|}{ Outcome } \\
\hline & $\begin{array}{c}\text { Representativeness of } \\
\text { exposed cohort }\end{array}$ & $\begin{array}{l}\text { Selection of non- } \\
\text { exposed cohort }\end{array}$ & $\begin{array}{c}\text { Ascertainment of } \\
\text { exposure }\end{array}$ & $\begin{array}{c}\text { Outcome not } \\
\text { present at start }\end{array}$ & & $\begin{array}{c}\text { Assessment of } \\
\text { outcome }\end{array}$ & $\begin{array}{c}\text { Adequate follow-up } \\
\text { length }\end{array}$ & $\begin{array}{c}\text { Adequacy of } \\
\text { follow-up }\end{array}$ \\
\hline Lee 2015 (16) & $*$ & $*$ & $*$ & $*$ & $*$ & $*$ & $*$ & $*$ \\
\hline Parkin 2017 (13) & $*$ & $*$ & & $*$ & $* *$ & $*$ & $*$ & $*$ \\
\hline Ray $2002(26)$ & $*$ & $*$ & $*$ & $*$ & $* *$ & $*$ & $*$ & $*$ \\
\hline
\end{tabular}


J Pharm Pharm Sci (www.cspsCanada.org) 22, 57 - 71, 2019

Table 4. Subgroup analyses and sensitivity analyses

\begin{tabular}{|c|c|c|c|}
\hline Category & No. of studies & OR $(95 \%$ CI $)$ & Heterogeneity, $\mathbf{I}^{2}(\%)$ \\
\hline \multicolumn{4}{|l|}{ Antidepressant } \\
\hline Total & $9(13-16,22-26)$ & $1.27(1.09,1.49)$ & 77.1 \\
\hline Low risk of bias & $2(14,26)$ & $1.27(0.84,1.92)$ & 91.1 \\
\hline High risk of bias & $7(13,15,16,22-25)$ & $1.30(1.12,1.51)$ & 54.9 \\
\hline Case-control studies & $6(14,15,22-25)$ & $1.38(1.17,1.63)$ & 52.1 \\
\hline Cohort studies & $3(13,16,26)$ & $1.12(0.85,1.47)$ & 87.3 \\
\hline Depressed patients & $1(16)$ & $0.72(0.39,1.31)$ & / \\
\hline Eliminate the effect of antipsychotics & $6(13-16,23,26)$ & $1.23(1.02,1.48)$ & 75.9 \\
\hline Female & $1(13)$ & $1.39(1.23,1.56)$ & 1 \\
\hline \multicolumn{4}{|l|}{ SSRI } \\
\hline Total & $5(13-16,26)$ & $1.10(0.90,1.34)$ & 62.3 \\
\hline Low risk of bias, SSRI & $2(14,26)$ & $1.05(0.94,1.18)$ & 0.0 \\
\hline High risk of bias, SSRI & $3(13,15,16)$ & $1.05(0.71,1.55)$ & 73.5 \\
\hline Case-control studies, SSRI & $2(14,15)$ & $1.01(0.74,1.38)$ & 13.2 \\
\hline Cohort studies, SSRI & $3(13,16,26)$ & $1.12(0.85,1.47)$ & 77.5 \\
\hline Depressed patients, SSRI & $1(16)$ & $0.75(0.40,1.38)$ & / \\
\hline Eliminate the effect of antipsychotics, SSRI & $4(14-16,26)$ & $1.02(0.92,1.14)$ & 0.0 \\
\hline Female, SSRI & $1(13)$ & $1.40(1.17,1.68)$ & 1 \\
\hline \multicolumn{4}{|l|}{ TCA } \\
\hline Total & $4(13-15,26)$ & $1.26(1.02,1.57)$ & 79.1 \\
\hline Low risk of bias, TCA & $2(14,26)$ & $1.20(0.77,1.89)$ & 84.3 \\
\hline High risk of bias, TCA & $2(13,15)$ & $1.34(1.17,1.54)$ & 0.0 \\
\hline Case-control studies, TCA & $2(14,15)$ & $1.45(1.19,1.77)$ & 0.0 \\
\hline Cohort studies, TCA & $2(13,26)$ & $1.13(0.85,1.52)$ & 87.5 \\
\hline Eliminate the effect of antipsychotics, TCA & $3(14,15,26)$ & $1.26(0.92,1.71)$ & 81.7 \\
\hline Female, TCA & $1(13)$ & $1.32(1.12,1.55)$ & 1 \\
\hline
\end{tabular}

SSRI $=$ selective serotonin reuptake inhibitor; $\mathrm{TCA}=$ tricyclic antidepressant. 
J Pharm Pharm Sci (www.cspsCanada.org) 22, 57 - 71, 2019

Table 5. GRADE evidence

\begin{tabular}{|c|c|c|c|c|c|c|c|c|}
\hline \multicolumn{7}{|c|}{ Quality assessment } & \multirow{2}{*}{$\begin{array}{l}\text { Summary of findings } \\
\text { Relative risk ( } 95 \% \mathrm{CI})\end{array}$} & \multirow[b]{2}{*}{ Quality of evidence } \\
\hline $\begin{array}{l}\text { No. of studies } \\
\text { (participants) }\end{array}$ & Risk of bias & Inconsistency & Indirectness & Imprecision & Reporting bias & Upgrading & & \\
\hline $\begin{array}{c}\text { Antidepressant } \\
9 \text { studies }(13-16,22- \\
26)\end{array}$ & $\begin{array}{c}\text { Serious } \\
\text { limitations }\end{array}$ & $\begin{array}{c}\text { Serious } \\
\text { limitations }\end{array}$ & $\begin{array}{l}\text { No serious } \\
\text { limitations }\end{array}$ & $\begin{array}{l}\text { No serious } \\
\text { limitations }\end{array}$ & Undetected & None & $1.27(1.09,1.49)$ & Very low \\
\hline $\begin{array}{c}\text { SSRI } \\
5 \text { studies }(13-16,26)\end{array}$ & $\begin{array}{c}\text { Serious } \\
\text { limitations }\end{array}$ & $\begin{array}{c}\text { Serious } \\
\text { limitations }\end{array}$ & $\begin{array}{l}\text { No serious } \\
\text { limitations }\end{array}$ & $\begin{array}{l}\text { No serious } \\
\text { limitations }\end{array}$ & Undetected & None & $1.10(0.90,1.34)$ & Very low \\
\hline $\begin{array}{c}\text { TCA } \\
4 \text { studies }(13-15,26)\end{array}$ & $\begin{array}{c}\text { Serious } \\
\text { limitations }\end{array}$ & $\begin{array}{c}\text { Serious } \\
\text { limitations }\end{array}$ & $\begin{array}{l}\text { No serious } \\
\text { limitations }\end{array}$ & $\begin{array}{l}\text { No serious } \\
\text { limitations }\end{array}$ & Undetected & None & $1.26(1.02,1.57)$ & Very low \\
\hline
\end{tabular}

SSRI selective serotonin reuptake inhibitor; $\mathrm{TCA}=$ tricyclic antidepressant. 